\title{
EDITORIAL
}

\section{Comunicação é ciência?}

\author{
Felipe Pena'
}

A cada nova edição da Contracampo questiono os objetivos das publicaçòes acadêmicas em nossa área e, consequentemente, o próprio papel dos pesquisadores que nela publicam. Por que alguns insistem em chamar de ciència um campo cujas reflexões se aproximam muito mais da arte? Até que ponto os critérios balizados pela Capes e CNPQ se aplicam à Comunicaçào? As revistas nào deveriam ter uma interlocução maior com setores de fora da universidade? Quem, de fato, lê o que publicamos? Por que utilizamos una linguagem pomposa e hermética se o que queremos é, em última instância, comunicar os resultados de nossas pesquisas?

A maioria de nós leciona em programas de pós-graduação de universidades públicas, o que nos obriga a ter um nível mínimo de produçào e a posterior vejculaçào em revistas indexadas. Este sentido pragmático talvez nos impeça de dar mais atenção às questòes acima, mas creio que não podemos deixar de abordá-las. Da mesma forma, sei que há um grande esforço para consolidar o campo como área de conhecimento, capitaneado por nossos mais experientes professores, o que merece todos os elogios e louvaçòes. Entretanto, empreender um trabalho questionador é uma forma de entriquecer esse mesmo esforço e não de inviabilizá-lo.

Já ouvi críticas a estes questionamentos sob o argumento de que não passam de um reducionismo, uma visão limitada de nossa ampla produção. Para tal argumento tenho duas respostas. Primeiramente, basta uma consulta quantitativa às principais publicaçōes da área para ver que a maioria dos textos tem caráter ensaístico-teórico, e nem mesmo a maior parte daqueles que se propòem empíricos apresenta dispositivos propriamente "científicos", seja no sentido das refutaçòes de Popper, das induçooes de Bacon ou de qualquer outro método que mereça tal epiteto .

Em segundo lugar, se estou sendo reducionista, esta é a natureza de minha própria argumentação, que é teórica, levanta uma hipótese. Se vou teorizar sobre determinado assunto, significa que quero enquadrá-lo sob um ponto de vista especifico. Mesmo que para isso utilize os mais diversos conceitos e as mais diversas metodologias. Ao final, meu trabalho acaba sendo reduzir os tais conceitos e as tais metodologias aos limites do próprio quadro teórico que proponho.

\footnotetext{
1 Felipe Pena é jomalista, escritor, psicanalista membor da AHP, professor do Programa de Mestrado e Doutorado em Comunicação da Universidade lederal Fluminense c Doutor con litcratura pela PUC-Rios, com pós-doutorado em Semiologia da L magem pela Universidade de Paris / Sorbonnc lll. Foi repórter da TV Manchete, comentarista da TV1:-Brasil c sub-rcitror da UNJSA, onde tambem ocupou o carge de Diretor da laculade de Comunicação Social. É ediror-chefe da revista Contracampo e autor de oito livers na área academica, entre eles Teoria do Jornalismo (Fd. Concexto, 2005), traduzido para o espanhol, c Teoria da Biografin som fim (Ld. Mauad, 2004). Como romancista, publicou () analfabeto que passou no restibular (1ied. 7 teeras, 2008) e prepara sua segunda obra de ficção. Site pessoal: "ww:felipepena.com
} 
Então, para que produzir teorias nas mais diversas áreas do conhecimento? Resposta: para aprofundar o conhecimento sobre elas. Por mais paradoxal que pareça, reduzir também é ampliar. Quando faço um recorte sobre um tema, meus métodos de análise promovem questões que podem servir para incentivar a criação de outros métodos, que vão produzir novas questões e assim por diante. A pertinência de qualquer debate está nas perguntas, não nas respostas.

Com tal intenção, rabisquei as linhas acima. Provavelmente, incorro nos mesmos erros que aponto, mas espero contribuir para ampliar as discussões sobre o assunto. Nas páginas a seguir, o leitor encontrará textos ligados às mais diversas orientações teóricas. Todos merecem a sua atenção.

Boas reflexões! 